Clayton, B. and Coates, E. (2015) Negotiating the climb: A fictional representation of climbing, gendered parenting and the morality of time, Annals of Leisure Research Vol.18 No.2 pp235-251 doi: 10.1080/11745398.2014.957221

\title{
Negotiating the climb: A fictional representation of climbing, gendered parenting and the morality of time
}

\section{Prologue}

While recognising Kay's (2000) call to broaden empirical research to reflect the growth of non-traditional family forms, and acknowledging those attempts to answer such a call in leisure and sport studies (e.g. Bagley, Salmon and Crawford 2006; Dagkas and Stathi 2007; Quarmby and Dagkas 2010), we also recognise a residual gap in the existing literature about leisure patterns and experiences in the traditional, dual-parent family. Much of the research on family leisure has considered the impact that parenting has had on mothers' time and access to leisure, taking a critical feminist approach to analyse the sacrifice of time that mothers make, in part, by putting their children first (Bittman and Wajcman 2000; Brown et al 2001; Kimmel and Connelly 2007). More recently, the literature has expanded to consider fathers who support their children’s involvement in sport (Coakley 2006; Kay 2007). However, there has been a general lack of consideration, particularly within the adventure sport literature, of how parents maintain their involvement in sport or leisure following conception and the birth of their child(ren) (for some notable exceptions see Robinson 2008; Spowart et al 2008, 2010; Summers 2007; Wheaton and Tomlinson 1998).

This paper employs the creative non-fiction tradition to explore the experiences of heterosexual dual-parents who rock climb and their negotiation of competing leisure discourses and demands at the weekend, primarily the Saturday. From the outset, we take the position that the weekend is the prime space for 'family leisure' and, moreover, a space in which one's identity is not fixed or separate from other spheres, for example as a father/mother/husband/wife and climber (Lupton and Barclay 1997) and that 'these subject positions might stand in complete contradiction to each other' (Helstein 2007, 85). In this sense, we acknowledge that our 'story' originated as part of a broadly Foucauldian agenda. It is especially infiltrated by Foucault's (1972) central ideas of discourse as language as a source of thought and as a relativised $a$ priori constraint placed, in any given time and space, on how people think and subsequently act. In other words, discourse provides the 'conditions of possibility' for thought, which are contingent on the particular historical situation (Foucault 1970). Because such conditions are relative, not only do discourses change but 
Clayton, B. and Coates, E. (2015) Negotiating the climb: A fictional representation of climbing, gendered parenting and the morality of time, Annals of Leisure Research Vol.18 No.2 pp235-251 doi: 10.1080/11745398.2014.957221

multiple discourses shape human life (Markula and Pringle 2006) and alternative discourses compete for attention. However, a strict Foucauldian reading of the lifeworld of parents who climb is not our primary concern in this paper (for such a reading see Coates 2012) and we also draw on ideas about the reflexivity of latemodernity and the move beyond the binaries of modern social thought toward an incorporation of uncertainty and contingency (see Heaphy 2007). What we really seek is an authentic representation that might provide a platform for debate about gendered, moral parenting and serious leisure discourses. That is to say, while our analytic lens and written account is coloured, but not saturated by a Foucauldian and late-modern thesis, this is intended to be neither hidden nor obtrusive and we note it here only as a pre-story and epistemological confession of sorts.

\section{Stories of parents who climb: Methods and fictional representation}

The use of a variety of fictional techniques has become a common feature of studies examining diverse phenomena particularly in sport-related research (see for example, Bruce 2000; Clayton 2010, 2013; Douglas and Carless 2010; Grenfell and Rinehart 2003; Jones 2006; Rowe 2000; Sparkes 1996; see also Denison and Markula 2003). Scholars that employ or support the use of fictional representation regularly purport, as their first 'defence', an ethical imperative to disguise the identity of participants where fictive text can assure greater anonymity (Angrosino 1998 cited in Sparkes 2002, 150; Coffey and Atkinson 1996). However, fictional techniques can also provide authors with the tools to write more inclusive representations that do not obscure possible alternative readings and effectively present 'the inconvenient truth of [a story] that [has] been unheard' (A. Frank 2000, 363). Such a story may provide a greater sense of 'reality' where the lived-experience is complex and perhaps not possible to convey using theoretical explication alone (K. Frank 2000), thus offering something 'more ethical, less constraining [and allowing for] more balanced representations [of people and phenomena], complexities, contradictions, contingencies and all’ (Clayton 2013, 216).

It is these sentiments that have drawn us toward the creative non-fiction tradition to convey a 'typical weekend' (albeit the story concentrates on the Saturday) for parents who climb. The story that follows is the product of one of the authors' doctoral research (see Coates 2012), which examined the process of negotiation of competing 
Clayton, B. and Coates, E. (2015) Negotiating the climb: A fictional representation of climbing, gendered parenting and the morality of time, Annals of Leisure Research Vol.18 No.2 pp235-251 doi: 10.1080/11745398.2014.957221

discourses of climbing and parenting faced by seven heterosexual couples. It became apparent early in the analysis that the lived-experiences of these couples were complex and multifaceted and could not be done justice in a 'realist tale' (see Sparkes 2002; Van Maanen 1988). Instead, we adopt Richardson's (1994) view that the written account is not simply a way of 'telling', but can (and should) be a way of 'knowing' and 'showing' a reality for a proactive reader (see Sparkes 2002). While we are grounded by our own analytic conventions and conceptual signposts we reject a foundationalist stance in favour of dialogue and a communicative and pragmatic concept of validity (Lincoln and Guba 2003) and submit our story for 'unremitting reflection' (Clayton 2013, 207) where the 'truth' is to be found in the reader's response - a 'storied response to a story heard' (Smith and Sparkes 2011, 39). As a consequence, we consciously omit a traditional literature review as a textual staging or vestibule for subsequent empirical post-mortem, but acknowledge our association with the literature by way of an irregular, concomitant narrative and an 'epilogue' that summarises the main themes as we see them in a more general way via some of the conceptual and empirical literature that resonates with our story.

Like all fictional representations, the story is the result of 'being there' (Sparkes 2002), where data were collected by way of traditional qualitative methods. The seven couples were selected using purposive and snowball strategies, and had at least one child and both parents had pursued climbing, in some form, as serious, hobbyist leisure for a number of years prior to the conception and birth of their children. With the exception of one of the mothers, all the parents in the sample were still climbing at the time of the research and had been climbing for at least eleven years. All participants were white-British with ages ranging from 32-years to 62-years and the age of their children was from six-months to 27-years, with one couple expecting their second child. Only one couple had grown-up children at the time of the research and were asked to recall their experiences of when their children were young. While we were not immediately disposed to use the experiences of this couple to inform the story, we found that there was more continuity than change in the couples' experiences of parenting. All participants were university educated, including five doctorates and a further five post-graduates, and all worked as professionals in the service industry. As a consequence, while socio-economic position was not an intended feature of this or the original research - and the coincidental sample might 
Clayton, B. and Coates, E. (2015) Negotiating the climb: A fictional representation of climbing, gendered parenting and the morality of time, Annals of Leisure Research Vol.18 No.2 pp235-251 doi: 10.1080/11745398.2014.957221

suggest something about the relationships of social class and climbing as a leisure pursuit and social class and traditional family structures - we recognise that the story below may only be representative of, and garner an empathetic response from, a fairly exclusive section of the leisure community. Participants were interviewed individually in the couples’ own homes, with each parent in a couple interviewed consecutively following a topical, life-history narrative approach (see Wengraf 2001). Interviews were supported by a sustained period of observations at climbing walls and crags and in the participants' homes. The data were produced principally in the year between autumn 2010 and autumn 2011 in the Peak District National Park region of the UK, in central England.

Our focus in this paper is the multiple and competing discourses of parenting and climbing that are encountered at the weekend. Therefore this paper has concentrated on data concerned with family activities and climbing experiences specifically at the weekend, or data that alludes to 'family time', where neither parent is at (paid) work. Part of the 'fiction' of the story is that the events depicted transcend time and space and therefore while the story aims to represent a typical weekend scenario, raw data were not necessarily concerned with any one weekend. The story contains no 'pure' fiction, but is a partial account derived from empirical data sometimes using untainted duplications of witnessed actions or naturally-occurring talk, or responses taken from interview, explicitly relayed or paraphrased and woven into the story as words from the mouths of actors, or as internal thoughts of actors, or as the narrative that ties the story. The actors themselves are not facsimiles of participants and, rather, the experiences of all of the couples are condensed into the single experience of the story's primary couple, Liz and Jack, and the supporting actors they encounter through the story. The story, then, using fictional techniques, attempts to 'capture a sense of the subjects' world' (Markula and Denison 2005, 168) not by reporting the 'reality' but by 'replicat[ing] the sense of experience' (Rinehart 1998, 204) and allowing the reader to viscerally inhabit the lifeworld in order to create a better sense of reality. As Smith and Sparkes (2011) suggest, one reading of the story will compete for attention with others and the reality is to be found in the situated reader's response to it.

\section{Friday evening}


Clayton, B. and Coates, E. (2015) Negotiating the climb: A fictional representation of climbing, gendered parenting and the morality of time, Annals of Leisure Research Vol.18 No.2 pp235-251 doi: 10.1080/11745398.2014.957221

Darkness descends over the Nottingham suburb. Jack swings his bike from the road, the beam of his mounted cycle lamp momentarily slicing across the rose bushes and the front of his house before saturating the garage door with an eerie glow. He glides to a near-stop and expertly dismounts and, one hand on the rear of the saddle, pushes his bike through the gate, the back garden and into the shed. The light from the kitchen and upstairs bedroom tumbles across the lawn, providing just enough visibility for Jack to secure the padlock on the shed door and dodge the strewn plastic toys as he makes his way to the house. On entering, he contentedly inhales the roving aroma of tomato, garlic and onion that is escaping the pan on the stove.

"Liz? Sam?"

"Up here."

"Be up in a minute." Jack jangles his keys and drops them to the table where a messy spread of fresh finger-paintings near covers the somewhat congested calendar. Appointments, meetings, work event, Sam's nursery, Sam's play date. Saturday: Sam's friend's birthday party, recently struck through with red pen and 'CHICKENPOX' written boldly underneath.

"Good!" Thinks Jack to himself with only a momentary sense of remorse. Sunday: Sam's swimming class, only an hour but slap-bang in the middle of the day! "Out for a climb Saturday then."

Jack lazily kicks off his shoes and gropes his way through the dimly lit hall, nearly knocking the vase of assorted roses and lilies from the small, decorative table near the front door. He ascends the stairs on his toes, remembering to lunge over that squeaky step - fourth from the top - which so often has been his downfall late at night. He brushes against the wall adjacent to the bathroom door and smiles broadly as he listens to Sam splashing in the bath and talking about his day at nursery.

"And then I coloured in a wabbit and, um, mummy, in playtime I have been going woar at the girls like this... WOAR!"

"Boo!" Jack jumps two-footed into the doorway. Sam's arms fly upwards out of the bathwater, soaking Liz on her perch at the side of the bath.

"Thank you, daddy", she says sardonically, scooping the bubbles from her blouse and flicking them back into the bath.

"DAdddddyyy!" Sam shouts.

"Just at the girls, hey?” Jack winks at Liz. "Hello, wife."

"Hello, husband." Liz retorts.

Jack leans in and kisses her, and at the same time reaches over and tickles Sam, being careful to avoid the splashes. "How was your day, beautiful? Did you sort things out with that student?"

"Not much was resolved but I'll tell you about it over dinner," Liz sighs.

"Look at me, look at me." Sam shrieks frenziedly, with a layer of white bubbles over his top lip. "I've got um m-m-mustard just like gran-pops."

Liz smiles. "It's moustache, Sam. You try and sound it out after me. M-ust-o-sh." Sam repeats it slowly, getting it right the second time... more or less. "Clever boy! Right, I think you must be very clean now, so how about you put the toys in the basket and we get you ready for bed?"

"Oh, but mummy..." Sam begins to argue.

"Sam." Jack's firm tone provides enough impetus for Sam to reluctantly begin putting his toys away. 
Clayton, B. and Coates, E. (2015) Negotiating the climb: A fictional representation of climbing, gendered parenting and the morality of time, Annals of Leisure Research Vol.18 No.2 pp235-251 doi: 10.1080/11745398.2014.957221

"All done." Sam grins, standing up and putting his arms out.

"Well done Spam, aren't you a good boy?" Jack wraps a towel around him and lifts him out of the bath. He turns to Liz, "So are we climbing tomorrow?"

"Yes, absolutely. We must get out. Sam's party has been cancelled."

"Yes, so I saw." The same guilty smile comes across Jack's face.

"Don't be so mean," Liz chastises him, albeit with a mischievous smile of her own. "Poor Harrison. It was awful when Sam had chickenpox. Anyway, I've already spoken to Emma so we're set for tomorrow."

"Great," Jack grins. "I did text Mike and Lee but wasn't sure then if we were out. Mike did suggest Millstone. He wants a re-match on London Wall. What do you think?”

"Hmm, I would like to do Great North Road but it might be better for later in the year. The forecast looks like it might be quite windy and cold. So maybe we should go somewhere more sheltered. Maybe bouldering that we can all do? Sam could do a bit of climbing then too?"

"Okay, fair enough. I'm sure Lee and Caroline would prefer it if we're bouldering anyway, although I think they can only get out for a bit in the afternoon"

"Let's just see what it's like tomorrow." Liz finally manages to get a wriggling Sam into his bed-time nappy and pyjamas. "Right, I think its sleepybabies time for you. Who's reading the first story tonight?"

"Um... mummy!" Sam jumps up in the air. "Then daddy, then mummy again, then daddy..."

For Jack and Liz, like Featherstone (2009) says, the weekend is an important time for the reaffirming of family life. While they work at their thoroughly middle class jobs, Sam is placed in nursery and outside of nursery hours ad-hoc arrangements are made. They draw, as they always have, on discourses of individualism; the same discourses that have given them their thoroughly middle class existence and provided for their son, including paid childcare. But with their son came a shrinking of individual freedoms and a simultaneous acceleration of time. In a political culture that extols both the ethic of work and the ethic of care (Gerson 2009) time is both a political and a moral issue. Family time is tied-up with family values, the latter of which may often be equated to a hostile response to changes in family life and sexual behaviour (Weeks 1995), part of a steadfastly hegemonized morality. Foucault (1972) may argue that morality is a normative behaviour with the power to discipline Jack and Liz, but equally no form of morality can be acceptable to all and they have learned to negotiate the omnipresent menace of discourses of 'good parenting' and the moral pluralism of late-modern times. They are climbers, for as long as either of them can remember, guided by discourses of a commitment to authenticity (Rinehart and Sydnor 2003; Wheaton 2004) and voluntary risk taking (Heywood 2006; Lewis 2004; McNamee 2007). Now they 
Clayton, B. and Coates, E. (2015) Negotiating the climb: A fictional representation of climbing, gendered parenting and the morality of time, Annals of Leisure Research Vol.18 No.2 pp235-251 doi: 10.1080/11745398.2014.957221

are parents, for as long as either of them cares to remember, guided by an overwhelming and confusing plethora of parenting discourses even the most alternative of which appears risk adverse and governed by the ideology of intensive parenting (Furedi 2008). Their negotiations of these discourses lead them to what at first they perceive to be a space for both them and Sam, a space where 'being with' Sam supersedes without prohibiting 'being there' for him (Such 2006, 2009). This space is family leisure, or a family climb. That the space is formed and sustained more by Jack and Liz's self-interested, individualised identities as climbers is a moral wrangling that can be off-set and legitimised even amidst discourses of intensive parenting by the fact that it remains family leisure and that it remains lower in the hierarchy of time than Sam's leisure. That is to say, it fills the gaps in Sam's leisure lifeworld.

\section{Saturday}

6:30am

"MUUUMMMY!" The human alarm tears across the landing and ricochets around the house, waking Liz from her dreams. She rolls from the bed as the pitter-patter of feet grows louder and two blue eyes peer through the crack in the door. Jack groans and turns on his side.

"Don't worry, I'll go", Liz whispers, perching on the bed and rubbing her eyes. She slides her feet into her slippers and drags herself up and through the door.

\section{7:30am}

Jack turns off the shower tap and emerges through the cloud of steam, vigorously towelling his deep brown hair. He wraps the towel around his waist, lodges a toothbrush into his cheek and walks back to the bedroom. He peeks through the curtains to reveal an unwelcoming dull grey and then riffles through his drawers and wardrobe in search of his thermals, khaki trousers and fleece.

"What do you think? Somewhere with bouldering options?" He calls down the stairs. "Maybe Stanage Plantation? Car park at ten?"

"Yeah, that's maybe a better idea," comes a delayed response. "It's looking too cold for Sam to be sitting around all day, but the wind is low so we could do some routes first. I'll text Emma."

Jack grabs his phone from the bedside table and slumps on the bed. He puffs out his cheeks and with a purposeful, rapid exhale pulls up Mike's number. "Mike will understand," Jack thinks to himself. "Plans change when you have kids. Mike knows that."

He hurriedly texts the new plan and throws down his phone on the pillow and trots downstairs. Sam is on the kitchen floor pulling a train around an unsoundly and illogically designed wooden track while Liz slices sandwiches into 
Clayton, B. and Coates, E. (2015) Negotiating the climb: A fictional representation of climbing, gendered parenting and the morality of time, Annals of Leisure Research Vol.18 No.2 pp235-251 doi: 10.1080/11745398.2014.957221

neat triangles, wraps them and places them methodically into the lunch-bag. Jack fumbles through various drawers and cupboards and lines-up the day's supplies on the table: gear, rope, harnesses, climbing shoes, chalk bags, finger-tape, firstaid kit, baby wipes, spare nappies, toy cars and picture books. Bouldering mats are already in the car.

Foucault (1984) and others, such as Bauman (1993), may write that it is indicative of post-modernity - or perhaps a postmodern turn to the late-modern - that we take a more considered and eminently flexible approach to ethics and to morality itself. As Jack and Liz demonstrate the morality of time for parents is negotiated in context (see Smart and Neale 1998) and where the increasingly questioned powerknowledge threatens to rupture self-identity the subject must surely become 'undisciplined' in order to reconstitute the self (c.f. Heaphy 2007). However, inscribed selfhood may be more difficult to reconstitute than the context that calls for the reconstitution. The contestation in Jack's and Liz's identities as both parents and climbers provided the tools and motivation to reconstitute time and space, rather than the self, so that both family and self might benefit. It is a balance of individual choice and family responsibility (Ribbens McCarthy et al 2000) where serious, hobbyist time becomes family time and the crag the space for family leisure. A sacrifice is of course made but who, we may ask, might sacrifice the most? For Jack, or so he might have us believe, the identity imperatives at stake here are greater than for Liz where climbing has been a site for the (re)production of hetero-normative masculinities and homosociality (Robinson 2008). The limited versions of masculinity prescribed by modernity constrain women's leisure relative to their male partners (Such 2009), but the democratisation of gender of late-modernity renders any idea of the male self far less certain. In turn, fatherhood and indeed husbandhood become equally tinged with uncertainty calling for a reconstitution of these identities and a concomitant readdressing of homosocial relations. Femininities have arguably remained more constant and motherhood, Guendouzi (2006, 902) finds, is 'a product of both hegemonic institutional discourse and discourse expressed by women' themselves. This is in part, perhaps, because of the 'network of medicalisation' (Foucault 1984) that has forefronted the biological aspects of motherhood (growing, carrying, giving birth, breast-feeding) for maternal and, accordingly, feminine identity (Lee 2008) as part of a gendered and child-centred parenting ideology (Faircloth 2009; 
Clayton, B. and Coates, E. (2015) Negotiating the climb: A fictional representation of climbing, gendered parenting and the morality of time, Annals of Leisure Research Vol.18 No.2 pp235-251 doi: 10.1080/11745398.2014.957221

Knaack 2005). As such, we postulate, Liz's sacrifice is greater though perhaps less painful to rationalise.

\subsection{0am - Stanage Plantation}

Emma and Bill's mud-streaked Fiesta swings into the nearly full car park at the popular end of Stanage. Sam - wrapped in so many layers to be almost spherical - waddles quickly towards them as they exit the car. They had watched over Sam a number of times since Liz met them at a local climbing club shortly after Sam was born. Emma was as bubbly as Bill was quiet. Neither was a serious climber and instead preferred kayaking, but they loved the gritstone and were always keen to get out and were flexible on time and destination, which was just what Liz and Jack needed these days.

"Hello you three", Emma greets Sam with open arms. "So nice to be getting out at last", she says, sweeping her long brown hair into a ponytail.

"Oh, I know", Liz agrees. The rain and snow over the winter had led to many long hours and money spent at indoor bouldering walls around the Peak.

The group begins the walk up the path to the crag. Sam at a half run doesn't take long to stumble and fall. He begins to cry.

"It's alright, little man, you're okay," Jack helps him to his feet. "Just watch where you are going. Daddy will walk a bit slower." He engulfs his son's small hand and leads him slowly to the crag where Mike is warming up at the Goliath area,

"Are you sleeping at the crag now?" Jack shouts from a distance.

"I've only got this morning before I'm on double-trouble duty, so no wasting time for me," Mike replies.

"Didn't fancy bringing the twins out today then?"

"You must be joking, they're a nightmare at the crag, not like your young man here" Mike ruffles Sam's hair as he and Jack shake hands. "They get bored and start wandering about and then neither of us get any climbing done. Anyway, they're at another bloody birthday party this morning, but Becky might join us once she's dropped them."

"Believe me, Sam has his moments too," Liz interrupts, leaning in to kiss Mike on the cheek. "Not that that stops my husband from climbing, of course."

"I don't know what you mean," Jack raises his arms in mock protest. "But if that's how you feel, my darling, perhaps you would like to climb first with Emma and Bill can climb with Mike. If that's okay with everyone? And Mike, we could get a top rope on Indian Summer after?"

"Like your thinking. Right Bill, we'll go have a look at a couple of the E1's and 2's up here." Mike is clearly itching to get back to climbing as he and Bill gather their bags and move along the rock face.

"Ready, Liz? You get first lead," Emma retrieves a tatty guidebook and flicks through the well-read, yellowed pages. "Oh, how about Goliath's Grove? HVS 5a? Or do you want to warm up first?"

"No, best just jump straight in. It's not like I'll have time for a second route," Liz smiles as she watches Sam pushing his toy cars around the stones on the path. She takes a deep breath and exhales brusquely. "Right, let's do this before I talk myself out of it. It's been a while." 
Clayton, B. and Coates, E. (2015) Negotiating the climb: A fictional representation of climbing, gendered parenting and the morality of time, Annals of Leisure Research Vol.18 No.2 pp235-251 doi: 10.1080/11745398.2014.957221

Liz looks the route up and down, preparing herself with a number of short, sharp pants. "Loads of friends in the first crack, you can do E1 5a, Liz. How hard can it be?" She persuades herself. "Right, love you. Keep Sam warm."

"Of course. Have fun," Jack tells her.

Liz walks tentatively to the base of the route. She checks her harness, ties onto the rope, and pulls on her helmet and rock-shoes.

"You're on belay, so whenever you're ready, Liz," Emma says.

"Ready? Right, here we go, I'm climbing." Liz smiles broadly at Emma whilst simultaneously taking in a very deep breath. She dips her hands in her chalk bag and with one last pant starts gingerly up the face, struggling to get very far before wedging a foot in a crack. "Well, this is pretty desperate," she mutters to herself, putting her free hand to her forehead and smearing chalk dust down her cheek.

"Mummy, hello," Sam's voice reverberates around the enclosed landscape. Liz tries to block him out. "I need a wee-wee, Mummy."

"Okay, darling," Liz calls back, trying to disguise her exasperation. "Jack, do you think you could sort him out?"

"No!" Sam begins to cry. "Mummy takes me."

"Don't be silly, Sam. You can see mummy's up there," Jack says firmly.

Liz closes her eyes and pushes her forehead to the rock face. "Go with daddy, Sam. Mummy will be done very soon," she says. "Look at that boulder, Sam. After your wee, why don't you do what mummy's doing? Climb the rock like mummy, yes?"

\section{$1.15 \mathrm{pm}$}

"Lunch is ready, Sam," Liz calls. Sam slips down the few inches from the rock he is clambering on to the ground and runs hurriedly toward the picnic blanket. Jack unwraps a cheese sandwich, hands Sam a triangle and peals the plastic lid from a container of strawberries and places it down on the blanket.

"Daddy's going to go for a climb with Uncle Mike now. Okay, Sam?” Jack asks. Sam gives a pronounced nod, his cheeks near bursting as he chews. "And later you and me can do some climbing together while mummy does another route. That'll be good, won't it, Sam?"

Sam immediately stops chewing. His jaw drops to reveal a soggy ball of masticated bread and cheese lodged between his tongue and teeth. His eyes well. "No! Mummy climbs with me," Sam wails. Jack rolls his eyes and looks to Liz.

"It's okay, Sam. Mummy's not going anywhere." She hugs him and turns to Jack. "It was a nice thought, thank you."

Indeed, the sacrifice of time is undoubtedly gendered. Feminist research has shown us how women in employment effectively take a double-shift; paid work followed by the majority of domestic responsibilities, making a commitment to personal leisure that much harder than for a male partner (Hays 1996; Hochschild 1989; Pfister 2001). In socio-history, leisure, and especially sport, has had greater significance for men, associated as it is with masculine identity (c.f. Messner 1992; Messner and Sabo 1990), making a commitment to the personal leisure identity 
Clayton, B. and Coates, E. (2015) Negotiating the climb: A fictional representation of climbing, gendered parenting and the morality of time, Annals of Leisure Research Vol.18 No.2 pp235-251 doi: 10.1080/11745398.2014.957221

imperative. Such discourses remain strong, but late modernity has tainted them with uncertainty and necessitated a number of contingencies, such as the discourses of compromise and balance, which may produce an involved, flexible father (Such 2009), who's sense of self is established by performing a moral responsibility. Jack certainly experiences a degree of guilt about taking time for himself and has found that he is not alone in this as the changing construction of fatherhood causes his peers also to increasingly worry and strive to meet ideals of the selfless and caring father (Henwood and Procter 2003). Jack consciously reduces his climbing time to ensure he meets those requirements of late-modern family life, which ultimately allows him to enjoy - guilt-free - personal leisure and maintain a serious hobbyist identity. So, the gesture is not entirely selfless, we argue, and moreover the medicalisation of motherhood in many ways makes any such gesture rather futile. For Liz, discourses of the 'good mother' began with conception and she struggled with the competing discourses of the committed, voluntary risk-taking climber and risk adversity when pregnant (for full discussion see Coates 2012). Now, years later, while Sam is largely unscathed by Jack's temporary absence, the attachment he has to Liz has far greater ramifications for her personal leisure. Despite a strong desire to maintain a commitment to climbing and a degree of reflexive self-making, maintaining multiple versions of the self, Liz continues to draw on 'conventions of selflessness' (Miller 2007), engaging in the moral project to marginalise all 'other' identities and centre motherhood. Being on the margins is hard and has affected her confidence and in turn her ability to climb. Sam cannot climb with her, which then requires a decentring of motherhood, and that he is present, watching does not in itself create the space for family leisure. The 'being with' that Such $(2006,2009)$ speaks of requires a sharing of more than just physical space; there must be a sharing of the leisure experience. But when the experience is climbing, all new competing discourses may be tapped into.

\section{$3.40 p m$}

"Hey, how are you?" Liz embraces Caroline. "No Lee?"

"Yeah, he's here. I gave him a pass and let him go off for a bit. It means I get to spend some time with Connor."

"You're not climbing?" 
Clayton, B. and Coates, E. (2015) Negotiating the climb: A fictional representation of climbing, gendered parenting and the morality of time, Annals of Leisure Research Vol.18 No.2 pp235-251 doi: 10.1080/11745398.2014.957221

"Not today." Caroline looks to her feet and pushes her jaw to one side. "I've struggled with it a bit since Connor came along. I have other things now"

Liz perches on a rock and dumps her equipment at her feet. She reaches back and massages her tight shoulder. Caroline sits next to her and they watch Sam and Connor play. "What time did you get here?" Liz asks.

"Oh, a little while ago. Connor had his football this morning but we wanted to get out for most of the day. How was your climb with Emma?"

"Tough.” Liz says with a smile. "And knackering. But felt great."

Connor chases Sam along the winding path through the shrubs and back onto the main track, both screaming with excitement. "Boys, be careful." Liz warns. "Don't trip".

The boys continue their wild game, oblivious to Liz's words. Jack walks the track towards them, equipment weighing heavy in his arms. Sam runs to Jack butting him in the groin and wrapping his arms around his legs.

"Ugh," Jack crumples from the middle, half jokingly, and drops his gear to the ground. He embraces Sam and then ruffles Connor's hair. "Right, come on you two, fancy a bit of climb?"

"Are you sure?" Caroline interjects. "I don't know about... well, if Connor would..."

"I'm so sorry, Caroline," replies Jack with sudden realisation and penitence. "I just assumed you guys allowed Connor to have a go. Just bouldering, of course, and only the small ones. We'll be there the whole time."

"He doesn't have to." Liz stands and places her hand on Jack's shoulder to offer support. "It's just that now Sam is a bit bigger he sometimes likes to clamber a bit, nothing more than that really."

Caroline smiles. "I'm being silly, I know. Lee always says we should get Connor climbing but I don't like to push."

"No pushing," Jack replies grabbing his gear again and slinging it over his shoulder. "It's no different to what they do anyway when playing around the rocks, except that I can help a bit and stick the mats down so it's even safer, really. Lee already at the boulders?"

"Yes, he's been working on some problem since we got here. Not having much luck though." Caroline chuckles. The three begin to wander leisurely down to the boulders. Sam and Connor charge ahead, skipping over the bracken and talking noisily.

"We felt the same as you for a long time," Liz says to Caroline as they stroll down the path. "But Jack's friend, Aaron, got his kids going from an early age and then we kind of thought that 'they're here anyway, why not have a go?'"

"Aaron's eldest is getting good." Jack adds. "She's gonna be one to watch. Only six now I think, but real technical. Systematic in her approach, you know?”

"Boys, please be careful." Caroline shouts. "And don't go too far ahead."

No-one, Foucault would argue, is free from moral dilemmas or able to conjure a new morality that would relieve them of concerns, but some may invent practices that defraud the binaries of, for example, the natural and the perverse, domination and subordination, freedom and constraint (Weeks 1995). It would seem reasonable as well to suggest that some may be better at this - more able or 
Clayton, B. and Coates, E. (2015) Negotiating the climb: A fictional representation of climbing, gendered parenting and the morality of time, Annals of Leisure Research Vol.18 No.2 pp235-251 doi: 10.1080/11745398.2014.957221

disposed - than others. Liz and Caroline, one might argue, lived their lives in parallel until the conception of their children but Liz, for reasons perhaps beyond the scope of this paper, was able to reflect more critically, to juggle competing discourses without, as we have seen, rejecting one to conform to another (c.f. Foucault 1984). She is not alone here. Pederson (2001) and Little (2002) have demonstrated in their respective case studies how women athletes often strive for a status outside of motherhood after the birth of children, becoming more focussed on performing than ever before or at least focussed on improving steadily. The same can be said of Jack. A sacrifice of time for climbing has been made, but for Jack and Liz this does not correspond to a sacrifice of commitment, a rejection of discourses of improvement or 'climbing hard'. Rather, they have deconstructed these discourses and invented practices that allow them to reconstruct a climbing identity. Lee, too, has managed to do this, but his wife, Caroline's, identity is arguably far less fluid. The morality of time, those discourses of motherhood, the normalising and medicalising of a commitment to one's child, has had a more profound effect here; its intended, disciplinary effect. The discourses carry further messages about risk where parents are expected to virtually remove any possibility of risk or harm to children (James et al 1998; Lee 2008) under the panoptic gaze of the police, schools and social workers. Discourses of responsibility ensure that risk is gendered (Donnelly 2004; Laurendeau 2008) and fathers are far less prone to accusations of irresponsibility when partaking in precarious leisure (Summers 2007). Liz, however, is more defiant, or reflexive, in the face of discourses of modernity that, as Giddens (1992) may remark, would overwhelm us if it were not for the late-modern quest for authentic self-identity. The concept of authenticity is used here in a Foucauldian sense that rejects a fixed way of being and 'turns back to the idea that we have to be ourselves - to be truly our true self' (McNay 1992, 171 cited in Weeks 1995, 67). Jack and Liz, we argue, sought and continue to seek authenticity by prioritising the life and leisure of Sam but at the same time not deprioritising climbing's discourses of voluntary risk and commitment.

\section{Epilogue}

The depreciation of personal leisure time is inevitable with the conception and birth of children and is notoriously gendered, related as it is to both the historical primacy given to the maternal care of children (Davis 2008; Hollway 2006; 
Clayton, B. and Coates, E. (2015) Negotiating the climb: A fictional representation of climbing, gendered parenting and the morality of time, Annals of Leisure Research Vol.18 No.2 pp235-251 doi: 10.1080/11745398.2014.957221

Richardson 1993) and the gendering of sport and leisure spaces (Clarke and Humberstone 1997; Hargreaves 1994; Wearing 1998). As Draper (2000) notes, the mothering identity is clearly structured by expert, medical, legal and popular discourses, and this identity has been powerful in conveying that motherhood is a natural part of being a woman (Faircloth 2009; Gillespie 2001; Littunen 2002) and that a mother's leisure time is enduringly relational and for the consumption of others (Odih 1999, 2003), notably for partners and children (see also Wimbush 1988). Individuals become the bearers of discourse, internalising and acting out ideals of behaviour and so an awareness of self as mother has meant that mothers often express a sense of guilt at sacrificing time with their children to make time for themselves (Shaw 1994, 1997), including those mothers involved in outdoor or alternative sports (e.g. Spowart et al 2008) and particularly in climbing (e.g. Coates 2012; Loomis 2005; Stirling 2009). All the mothers depicted in our story expressed such sentiments. In the same way that discourses of intensive parenting felt and embodied by mothers are tied-up with dominant discourses of femininity (see for example Littunen 2002), discourses of fathering are regularly masculinised and involve shared time with children predominantly through play, sport and other leisure pursuits (Brandth and Kvande 1998; Brannen and Nilsen 2006; Dermott 2008; Kay 2006). As a consequence, changes to men’s leisure in the transition to parenthood do not necessarily mean a depreciation of leisure time, although upon fatherhood leisure becomes less individualised and more child-centred (Such 2009). Certainly, our story has shown how the fathers had more opportunity to climb and were more able to close out the fathering identity for a time, but also that they took an active role in encouraging their children to participate and to ensure that their partners had time and space to climb.

Indeed, in dual-working parent families, Nentwich (2007) suggests couples regularly work together to balance paid and domestic work and childcare, 'blurring the gender lines' (222) and allowing both mothers and fathers to more easily develop a self-identity outside of their parenting role. However, as our story has shown, such a view might be idealistic at best not only because of the medicalisation of motherhood but also, Quirke (2006) argues, because parents tend to overcompensate for time spent at work with an intensification of the parenting role, an obligation to provide a number of labour intensive activities for children 
Clayton, B. and Coates, E. (2015) Negotiating the climb: A fictional representation of climbing, gendered parenting and the morality of time, Annals of Leisure Research Vol.18 No.2 pp235-251 doi: 10.1080/11745398.2014.957221

that dominate family life (Laureau 2002). While our story has focussed on the parents' leisure, it is also made clear that such occasions were a rarity and needed to be actively created by a reflexive Jack and Liz, intent on finding some kind of authenticity. Indeed, the family calendar was dominated by Sam's leisure. Furthermore, there appears to be a general agreement that it remains the mother, more so than the father that feels the full force of the obligation of children's activities (Green et al 1990; Laureau 2002; Mattingly and Sayer 2006). Arguably, it is because of these competing discourses of intensive parenting and personal investment in leisure that leads parents like Jack and Liz, and the others depicted in our story, to sharing, or often pushing, their own leisure preferences as legitimate activities for children. While a few warnings about the perils of parental coercion exist in the field (e.g. Hellstedt 1987; Trussell 2009), the sharing of leisure and sport experiences is largely taken to be a positive action for children's longitudinal involvement and achievement in physical activity (Cote 1999; Hellstedt 1995; Lareau 2002; Woolger and Power 1993) and for family relations more generally (Gillis and Gass 1993; Harrington 2006). However, where those experiences are of forms of risk recreation, such as climbing, discourses of risk and risk management compete further with those of parenting and the related discourse of risk aversion (Maynard 2007; Robinson 2008). Coffey (2003, 2005) suggests that the risks taken in mountaineering (a particularly 'extreme' form of climbing) are often unquestioned within the climbing world - despite prominence in the national media and adventure sports literature (see Donnelly 2003; Laurendeau 2008; Palmer 2004; Summers 2007) - ignoring the potential costs of those risks, not to the climber but to his or her family and friends. As Robinson (2008) shows, climbers often take deliberate steps to circumvent the competing discourses of individual risk and responsibilities to dependents and others by avoiding forming close relationships and especially avoiding having children. Of course, our purposive sample may skew the reality here, but the traditional climbers in our story certainly did not avoid relationships with others but they were caught between a number of competing discourses, including those of the necessary and even celebrated discourses of risk taking (see Dougherty 2007; Ebert and Robinson 2007; Lewis 2004; Stranger 1999) and commitment to the activity (Rinehart and Sydnor 2003; Wheaton 2004; Wheaton and Beal 2003), and those of shared time and shared leisure with children (see Agate et al 2009; Freeman and Zabrieskie 
Clayton, B. and Coates, E. (2015) Negotiating the climb: A fictional representation of climbing, gendered parenting and the morality of time, Annals of Leisure Research Vol.18 No.2 pp235-251 doi: 10.1080/11745398.2014.957221

2002; Harrington 2006), and protecting children from risk and harm both directly (see James et al 1998; Lee 2008) and indirectly as a result of harm to the parent (see Coffey 2003; Furedi 1997; Oliver 2006). For parents who climb, then, a weekend of leisure is potentially fraught with the dangers of ostracism, experiences of guilt and contention around a lost leisure identity. The parents in our story, perhaps with the exception of Caroline, were critical of the legitimacy of such feelings of guilt and keen not to lose touch with their climbing selves. They juggled the competing discourses in a search for authenticity, whether they found it is matter for further dialogue.

\section{References}

Agate, J., R. Zabriskie, S. Agate and R. Poff. 2009. 'Family leisure satisfaction and satisfaction with family life'. Journal of Leisure Research 41 (2): 205-223

Angrosino, M. 1998. Opportunity House. London: Altamira Press

Bagley, S., J. Salmon and D. Crawford. 2006. 'Family structure and children's television viewing and physical activity'. Medicine and Science in Sport and Exercise 38 (5): 910-918

Bauman, Z. 1993. Postmodern Ethics. Oxford: Blackwell

Bittman, M. and J. Wajcman. 2000. 'The rush hour: The character of leisure time and gender equity'. Social Forces 79 (1): 165-189

Brandth, B. and E. Kvande. 1998. 'Masculinity and childcare: The reconstruction of fathering'. Sociological Review 46 (2): 293-313

Brannen, J. and A. Nilsen. 2006. 'From fatherhood to fathering: Transmission and change among British fathers in four-generation families'. Sociology 40 (2): 335352

Brown, P., W. Brown, Y. Miller and V. Hansen. 2001. 'Perceived constraints and social support for active leisure among mothers with young children'. Leisure Sciences 23 (3): 131-144

Bruce, T. 2000. 'Never let the bastards see you cry'. Sociology of Sport Journal 17 (1): 69-74

Clarke, G. and B. Humberstone, eds. 1997. Researching Women in Sport. Basingstoke: Palgrave MacMillan

Clayton, B. 2010. 'Ten minutes with the Boys, the thoroughly academic task and the semi-naked celebrity: Football masculinities in the classroom or pursuing 
Clayton, B. and Coates, E. (2015) Negotiating the climb: A fictional representation of climbing, gendered parenting and the morality of time, Annals of Leisure Research Vol.18 No.2 pp235-251 doi: 10.1080/11745398.2014.957221

security in a 'liquid' world?' Qualitative Research in Sport and Exercise 2 (3): 371384

Clayton, B. 2013. 'Initiate: Constructing the 'reality' of male team sport initiation rituals'. International Review for the Sociology of Sport 48 (2): 204-219

Coakley, J. 2006. 'The good father: Parental expectations and youth sports'. Leisure Studies 22 (2): 153-163

Coates, E. 2012. 'A fine balance: Stories of parents who climb'. PhD diss., Brunel University

Coffey, A. and P. Atkinson. 1996. Making Sense of Qualitative Data. London: Sage

Coffey, M. 2003. Fragile Edge: A Portrait of Loss on Everest. Huddersfield: Arrow

Coffey, M. 2005. Where the Mountain Casts its Shadow: The Dark Side of Extreme Adventure. New York, NY: St, Martin's Griffin

Cote, J. 1999. 'The influence of the family in the development of talent in sport'. The Sport Psychologist 13 (3): 395-417

Dagkas, S. and A. Stathi. 2007. 'Exploring social and environmental factors affecting adolescents' participation in physical activity'. European Physical Education Review 13 (3): 369-384

Davis, K. 2008. "Here's your baby, on you go': Kinship and expert advice amongst mothers in Scotland'. PhD diss., Monash University

Denison, J. and P. Markula. eds. 2003. Moving Writing: Crafting Movement in Sport Research. New York, NY: Peter Lang

Dermott, E. 2008. Intimate Fathering: A Sociological Analysis. London: Routledge

Donnelly, P. 2003. 'Sport climbing vs. adventure climbing'. In To the Extreme: Alternative Sports, Inside and Out, edited by R. Rinehart and S. Sydnor, 291-306. Albany, NY: State University of New York Press

Donnelly, P. 2004. 'Sport and risk culture'. In Sporting Bodies, Damaged Selves: Sociological Studies of Sports-Related Injury, edited by K. Young, 29-58. Oxford: Elsevier

Dougherty, A. 2007 'Aesthetic and ethical issues concerning sport in wilder places'. In Philosophy, Risk and Adventure Sports, edited by M. McNamee, 94-105. London: Routledge

Douglas, K. and D. Carless. 2010. 'Restoring connections in physical activity and mental health research and practice: A confessional tale'. Qualitative Research in Sport and Exercise 2 (3): 336-353 
Clayton, B. and Coates, E. (2015) Negotiating the climb: A fictional representation of climbing, gendered parenting and the morality of time, Annals of Leisure Research Vol.18 No.2 pp235-251 doi: 10.1080/11745398.2014.957221

Draper, J. 2000. 'Fathers in the making: Men, bodies and babies'. PhD diss., University of Hull

Ebert, P. and S. Robinson. 2007. 'Adventure, climbing excellence and the practice of 'bolting". In Philosophy, Risk and Adventure Sports, edited by M. McNamee, 5670. London: Routledge

Faircloth, C. 2009. 'Mothering as identity-work: Long-term breastfeeding and intensive motherhood'. Anthropology News 50 (2): 15-17

Featherstone, B. 2009. Contemporary Fathering: Theory, Policy and Practice. Bristol: The Policy Press

Foucault, M. 1970. The Order of Things: An Archaeology of the Human Sciences. London: Tavistock

Foucault, M. 1972. The Archaeology of Knowledge. London: Routledge

Foucault, M. 1984. 'On the genealogy of ethics: An overview of a work in progress'. In The Foucault Reader, edited by P. Rabinow, 340-372. New York, NY: Pantheon

Frank, A. 2000. 'The standpoint of storyteller'. Qualitative Health Research 10 (3): 354-365

Frank, K. 2000. 'The management of hunger'. Qualitative Inquiry 6 (4): 474-488

Freeman, A. and R. Zabrieskie. 2002. 'The role of outdoor recreation in family enrichment'. Journal of Adventure Education and Outdoor Learning 2 (2): 131145

Furedi, F. 1997. Culture of Fear: Risk-Taking and the Morality of Low Expectation. London: Cassell

Furedi, F. 2008. Paranoid Parenting: Why Ignoring the Experts May be Best for Your Child. London: Continuum.

Gerson, K. 2009. The Unfinished Revolution: Coming of Age in a New Era of Gender, Work and Family. New York, NY: Oxford University Press

Giddens, A. 1992. Modernity and Self-Identity. Cambridge: Polity

Gillespie, R. 2001. 'Contextualising voluntary childlessness within a postmodern model of reproduction: Implications for health and social needs'. Critical Social Policy 21 (2): 139-159 
Clayton, B. and Coates, E. (2015) Negotiating the climb: A fictional representation of climbing, gendered parenting and the morality of time, Annals of Leisure Research Vol.18 No.2 pp235-251 doi: 10.1080/11745398.2014.957221

Gillis, H. and M. Gass. 1993. 'Bringing adventure into marriage and family therapy: An innovative experiential approach'. Journal of Marriage and Family Therapy 19 (3): 273-286

Green, E., S. Hebron and D. Woodward. 1990. Women's Leisure: What Leisure? Basingstoke: MacMillan

Grenfell, C. and R. Rinehart. 2003. 'Skating on thin ice: Human rights in youth figure skating'. International Review for the Sociology of Sport 38 (1): 79-97

Guendouzi, J. 2006, “The guilt thing': Balancing domestic and professional roles'. Journal of Marriage and Family 68 (4): 901-907

Hargreaves, J. 1994. Sporting Females: Critical Issues in the History and Sociology of Women's Sport. London: Routledge

Harrington, M. 2006. 'Family leisure'. In A Handbook of Leisure Studies, edited by C. Rojek, S. Shaw and A. Veal, 417-432. Basingstoke: MacMillan

Hays, S. 1996. The Cultural Contradictions of Motherhood. New Haven, CT: Yale University Press

Heaphy, B. 2007. Late Modernity and Social Change: Reconstructing Social and Personal Life. London: Routledge

Hellstedt, J. 1987. 'The coach/parent/athlete relationship'. The Sport Psychologist 1 (1): 151-160

Hellstedt, J. 1995. 'Invisible players: A family system model'. In Sport Psychology Interventions, edited by S. Murphy, 117-146. Champaigne, Ill: Human Kinetics

Helstein, M. 2007. 'Seeing your sporting body: Identity, subjectivity, and misrecognition'. Sociology of Sport Journal, 24 (1): 78-103

Henwood, K. and J. Procter. 2003. 'The 'good father': Reading men's accounts of paternal involvement during the transition to first-time fatherhood'. British Journal of Social Psychology 42 (3): 337-355

Heywood, I. 2006. 'Climbing monsters: Excess and restraint in contemporary rock climbing'. Leisure Studies, 25 (4): 455-467

Hochschild, A. 1989. The Second Shift: Working Parents and the Revolution at Home. New York, NY: Penguin

Hochschild, A. 1997. The Time-Bind: When Work Becomes Home and Home Becomes Work. New York, NY: Henry Holt and Co.

Hollway, W. 2006. The Capacity to Care: Gender and Ethical Subjectivity. London: Routledge 
Clayton, B. and Coates, E. (2015) Negotiating the climb: A fictional representation of climbing, gendered parenting and the morality of time, Annals of Leisure Research Vol.18 No.2 pp235-251 doi: 10.1080/11745398.2014.957221

James, A., C. Jenks and A. Prout. eds. 1998. Theorising Childhood. Cambridge: Polity

Jones, R. 2006. 'Dilemmas, maintaining 'face', and paranoia: An average coaching life'. Qualitative Inquiry 12 (5): 1012-1021

Kay, T. 2000. 'Leisure, gender and family: The influence of social policy'. Leisure Studies 19 (4): 247-265

Kay, T. 2006. 'Where's dad? Fatherhood in leisure studies'. In Fathering through Leisure, edited by T. Kay, 133-152. Eastbourne: Leisure Studies Association

Kay, T. 2007. 'Fathering through sport'. World Leisure Journal 49 (2): 69-82

Kimmel, J. and R. Connelly. 2007. 'Mothers' time choices: Caregiving, leisure, home production and paid work'. Journal of Human Resources 42 (3): 643-681

Knaak, S. 2005. 'Breast-feeding, bottle-feeding and Dr Spock: The shifting context of choice'. Canadian Review of Sociology 42 (2): 197-216

Laureau, A. 2002. 'Invisible inequality: Social class and childrearing in black families and white families'. American Sociological Review 67 (5): 747-776

Laurendeau, J. 2008. “Gendered risk regimes': A theoretical consideration of edgework and gender'. Sociology of Sport Journal 25 (3): 293-309

Lee, E. 2008. 'Living with risk in the age of 'intensive motherhood': Maternal identity and infant feeding'. Health, Risk and Society 10 (5): 467-477

Lewis, N. 2004. 'Sustainable adventure: Embodied experiences and ecological practices within British climbing'. In Understanding Lifestyle Sports: Consumption, Identity and Difference, edited by B. Wheaton, 70-93. London: Routledge

Lincoln, Y. and E. Guba. 2003. 'Paradigmatic controversies, contradictions and emerging confluences'. In The Landscape of Qualitative Research: Theories and Issues $2^{\text {nd }}$ ed., edited by N. Denzin and Y. Lincoln, 253-291. Thousand Oaks, CA: Sage

Little, D. 2002. 'Women and adventure recreation: Reconstructing leisure constraints and adventure experiences to negotiate continuing participation'. Journal of Leisure Research 34 (1): 157-177

Littunen, S. 2002. 'Gender equality or primacy of mothers? Ambivalent descriptions of good parents'. Journal of Marriage and Family 69 (2): 341-351

Loomis, M. 2005. 'Going manless'. The American Alpine Journal 47 (79): 98-115 
Clayton, B. and Coates, E. (2015) Negotiating the climb: A fictional representation of climbing, gendered parenting and the morality of time, Annals of Leisure Research Vol.18 No.2 pp235-251 doi: 10.1080/11745398.2014.957221

Lupton, D. and L. Barclay. 1997. Constructing Fatherhood: Discourses and Experiences. London: Sage

Markula, P. and J. Denison. 2005. 'Sport and the personal narrative'. In Qualitative Methods in Sports Studies, edited by D. Andrews, D. Mason and M. Silk, 165-184. Oxford: Berg

Markula, P. and R. Pringle. 2006. Foucault, Sport and Exercise: Power, Knowledge and Transforming the Self. New York, NY: Routledge

Mattingley, M. and L. Sayer. 2006. 'Under pressure: Gender differences in the relationship between free-time and feeling rushed'. Journal of Marriage and Family 68 (1): 205-221

Maynard, T. 2007. 'Encounters with Forest School and Foucault: A risky business?' International Journal of Primary, Elementary and Early Years Education 35 (4): 379-391

McNamee, M. ed. 2007. Philosophy, Risk and Adventure Sports. London: Routledge

McNay, L. 1992. Foucault and Feminism. Cambridge: Polity

Messner, M. 1992. Power at Play: Sports and the Problem of Masculinity. Boston, MA: Beacon Press

Messner, M. and D. Sabo. eds. 1990. Sport, Men and the Gender Order: Critical Feminist Perspectives. Champaign, Ill: Human Kinetics

Miller, T. 2007. 'Is this what motherhood is all about?' Weaving experiences and discourses through transition to first-time motherhood'. Gender and Society 21 (3): 337-358

Nentwich, J. 2007. 'New fathers and new mothers are gender troublemakers? Exploring discursive constructions of heterosexual parenthood and their subversive potential'. Feminism and Psychology 18 (2): 207-230

Odih, P. 1999. 'Gendered time in the age of destruction'. Time and Society 8 (1): 9-38

Odih, P. 2003. 'Gender, work and organisation in the time/space economy of 'just-in-time' labour'. Time and Society 12 (2-3): 293-314

Oliver, S. 2006. 'Moral dilemmas of participation in dangerous leisure activities'. Leisure Studies 25 (1): 95-109

Palmer, C. 2004. 'Death, danger and the selling of risk in adventure sports'. In Understanding Lifestyle Sports: Consumption, Identity and Difference, edited by B. Wheaton, 55-69. London: Routledge 
Clayton, B. and Coates, E. (2015) Negotiating the climb: A fictional representation of climbing, gendered parenting and the morality of time, Annals of Leisure Research Vol.18 No.2 pp235-251 doi: 10.1080/11745398.2014.957221

Pederson, I. 2001. 'Athletic career: 'Elite sports mothers' as a social phenomenon'. International Review for the Sociology of Sport 36 (3): 259-274

Pfister, G. 2001. 'The everyday lives of sportswomen: Playing sport and being a mother'. In Women's Leisure Experiences: Age, Stages and Roles, edited by $S$. Clough and J. White, 75-86. Eastbourne: Leisure Studies Association

Quarmby, T. and S. Dagkas. 2010. 'Children's engagement in leisure time physical activity: Exploring family structure as a determinant'. Leisure Studies 29 (1): 5366

Quirke, L. 2006. “Keeping young minds sharp': Children's cognitive stimulation and the rise of parenting magazines, 1959-2003'. Canadian Review of Sociology 43 (4): 387-406

Ribbens McCarthy, J., R. Edwards and V. Gillies. 2000. 'Moral tales of the child and the adult: Narratives of contemporary family lives under changing circumstances'. Sociology 34 (4): 785-803

Richardson, D. 1993. Women, Motherhood and Childrearing. Basingstoke: MacMillan

Richardson, L. 1994. 'Writing: A method of inquiry'. In Handbook of Qualitative Research edited by N. Denzin and Y. Lincoln, 516-529. Thousand Oaks, CA: Sage

Rinehart, R. 1998. 'Fictional methods in ethnography'. Qualitative Inquiry 4 (2): 200-224

Rinehart, R. and S. Sydnor. eds. 2003. To the Extreme: Alternative Sports, Inside and Out. Albany, NY: State University of New York Press

Robinson, V. 2008. Everyday Masculinities and Extreme Sport: Male Identity and Rock Climbing. Oxford: Berg

Rowe, D. 2000. 'Amour improper, or Fever Pitch sans reflexivity'. Sociology of Sport Journal 17 (1): 95-97

Shaw, S. 1994. 'Gender, leisure and constraint: Towards a framework for the analysis of women's leisure'. Journal of Leisure Research 26 (1): 8-22

Shaw, S. 1997. 'Controversies and contradictions in family leisure: An analysis of conflicting paradigms'. Leisure Sciences 14 (3): 271-286

Smart, C. and B. Neale. 1998. Family Fragments. Cambridge: Polity

Smith, B. and A. Sparkes. 2011. 'Exploring multiple responses to a chaos narrative'. Health: An Interdisciplinary Journal for the Social Study of Health, Illness and Medicine 15 (1): 38-53 
Clayton, B. and Coates, E. (2015) Negotiating the climb: A fictional representation of climbing, gendered parenting and the morality of time, Annals of Leisure Research Vol.18 No.2 pp235-251 doi: 10.1080/11745398.2014.957221

Sparkes, A. 1996. 'The fatal flaw'. Qualitative Inquiry 2 (4): 463-494

Sparkes, A. 2002. Telling Tales in Sport and Physical Activity: A Qualitative Journey. Leeds: Human Kinetics

Spowart, L., J. Hughson and S. Shaw. 2008. 'Snowboarding mums carving out fresh tracks: Resisting traditional motherhood discourse?' Annals of Leisure Research 11 (1-2): 187-204

Spowart, L., L. Burrows and S. Shaw. 2010. "I just eat, sleep and dream of surfing': When surfing meets motherhood'. Sport in Society 13 (7): 1186-1203

Stirling, S. 2009. 'Mountaineering mums'. UK Climbing. Accessed March 2009. http://www.ukclimbing.com/articles/page.php?id=1739

Stranger, M. 1999. 'The aesthetics of risk: A study of surfing'. International Review for the Sociology of Sport 34 (3): 265-276

Such, E. 2006. 'Leisure and fatherhood in dual-earner families'. In Fathering Through Leisure, edited by T. Kay, 185-199. Eastbourne: Leisure Studies Association

Such, E. 2009. 'Fatherhood, the morality of personal time and leisure-based parenting'. In Fathering through Sport and Leisure, edited by T. Kay, 73-87. London: Routledge

Summers, K. 2007. 'Unequal genders: Mothers and fathers on mountains'. Sheffield Online Papers in Social Research. Accessed July 2008. http://www.shef.ac.uk/shop/10.html

Trussell, D. 2009. 'Organized youth sport, parenthood ideologies and gender relations: Parents' and children's experiences and the construction of 'team family". PhD diss., University of Waterloo

Van Maanen, J. 1988. Tales of the Field. Chicago, Ill: University of Chicago Press

Wearing, B. 1998. Leisure and Feminist Theory. London: Sage

Weeks, J. 1995. Invented Moralities. Cambridge: Polity

Wengraf, T. 2001. Qualitative Research Interviewing: Biographic Narrative and Semi-Structured Methods. London: Sage

Wheaton. B. ed. 2004. Understanding Lifestyle Sports: Consumption, Identity and Difference. London: Routledge 
Clayton, B. and Coates, E. (2015) Negotiating the climb: A fictional representation of climbing, gendered parenting and the morality of time, Annals of Leisure Research Vol.18 No.2 pp235-251 doi: 10.1080/11745398.2014.957221

Wheaton, B. and B. Beal. 2003. "Keeping it real': Subcultural media and the discourses of authenticity in alternative sport'. International Review for the Sociology of Sport 38 (2): 155-176

Wheaton, B. and A. Tomlinson. 1998. 'The changing gender order in sport? The case of windsurfing subcultures'. Journal of Sport and Social Issues 22 (3): 252274

Wimbush, E. 1988. 'Mothers' meeting'. In Relative Freedoms: Women and Leisure, edited by E. Wimbush and M. Talbot, 48-59. Milton Keynes: Open University Press

Woolger, C. and T. Power. 1993. 'Parent and sport socialization: Views from the achievement literature'. Journal of Sport Behaviour 16 (3): 171-189 